\title{
Recordar e escavar: a herança sistemática de Fichte no sistema espectral da linguagem de Walter Benjamin
}

Theofilo Moreira Barreto de Oliveira

\author{
(2) OpenEdition \\ Journals \\ Edição electrónica \\ URL: http://journals.openedition.org/ref/1089 \\ DOI: $10.4000 /$ ref.1089 \\ ISSN: 2258-014X \\ Editora \\ EuroPhilosophie Editions \\ Refêrencia eletrónica \\ Theofilo Moreira Barreto de Oliveira, «Recordar e escavar: a herança sistemática de Fichte no sistema \\ espectral da linguagem de Walter Benjamin», Revista de Estud(i)os sobre Fichte [Online], 18 | 2019, \\ posto online no dia 01 junho 2019, consultado o 26 janeiro 2021. URL: http://journals.openedition.org/ \\ ref/1089 ; DOl: https://doi.org/10.4000/ref.1089
}

Este documento foi criado de forma automática no dia 26 janeiro 2021.

() EuroPhilosophie 


\title{
Recordar e escavar: a herança sistemática de Fichte no sistema espectral da linguagem de Walter Benjamin
}

\author{
Theofilo Moreira Barreto de Oliveira
}

\section{NOTA DO AUTOR}

o presente título tem o propósito de fundamentar e remontar num sentido reverso do exposto por Walter Benjamin em seu texto original Escavar e Recordar o processo de estruturação do que chamaremos de Sistema Espectral da Linguagem presente em sua filosofia, como base do seu sistema filosófico da linguagem. BENJAMIN, W. 2013. Escavar e Recordar, in Sobre o haxixe e outras drogas. p. 101.

Pensar e escrever são fundamentalmente questões de resistência.

(...) A tarefa ética do [pesquisador contemporâneo] não é ser um criador, mas um destruidor - um destruidor da interiorização superficial,

[d]a ideia consoladora do universalmente humano, da criatividade diletantística e das frases vazias.

(Susan Sontag - Sob o signo de Saturno) 
1 Toda reflexão, mesmo a mais ambiciosa, desenvolvida até agora, com base num método aqui e ali talvez ainda vago, ainda impregnado de uma variedade de posicionamentos, converge, de fato, numa estrutura sistemática de linguagem e condensa-se num processo de tradução de uma multiplicidade nomeada que é finita ao nível da ideia, mas infinita ao nível do sentido. Só por isso esta exposição pode, e deve, insistir na estrutura sistêmica e aberta da linguagem, porque só graças ao processo de codificação da realidade, podemos assimilar como substância própria, os materiais que são nomeados pelas condições históricas de cada época. ${ }^{1}$

2 A necessidade que se faz aqui é a de que devemos em primeiro lugar, recordar no sentido de Erinnerung a experiência vivida da das Erlebt ${ }^{2}$ que Benjamin nos expôs através de sua narrativa. Percorreremos um caminho de múltiplos rastros, deixados de forma extremamente sutil. Rastros estes que nos conduzem para uma/sua proposta de sistema filosófico, oriundos de sua influência da filosofia fichteana ${ }^{3}$ até então sempre negada e apagada de seus escritos, como ele próprio havia mencionado a seu amigo Scholem ${ }^{4}$, como também da maioria de seus críticos e estudiosos.

3 Benjamin ao longo de sua existência, abordou uma grande variedade de temas. E necessariamente, entre um ponto e outro ele conectou cada um dos seus escritos através de uma estrutura invisível e travestida de fragmentária. No entanto, este travestimento se deu por necessário, para que ele, de certa forma, pudesse expor suas ideias, já que, ao longo de todos os seus relatos ${ }^{5}$, ele sempre esteve fadado ao fracasso em vida. Desta forma, seguindo na contramão do que se tem dito a respeito da filosofia de Benjamin, nos propomos aqui a afirmar e seguir este contrafluxo. Muitos dos seus críticos, estudiosos e seguidores de seu pensamento, afirmam que não há um sistema ou uma estrutura sistemática em sua filosofia.

4 Normalmente se fala em constelações, em conexões, estilo ensaístico, mas nunca numa sistematicidade ou de um sistema existente. Há ainda quem diga, que sua sistematicidade é a própria fragmentação como escreve Augustin Wernet na apresentação da edição brasileira do livro de Rainer Rochlitz $O$ desencantamento da arte. Segundo Augustin Wernet ainda, Rochlitz expõe que "existe a possibilidade subjacente aos muitos discursos e sistemas de comunicação, devido ao poder criativo da linguagem"6. Ele ainda continua:

Geralmente se chama a atenção para a diversidade de formas, temas e concepções que se sobrepõe e se sucedem em sua obra. Ressalta-se a sua capacidade de projetar incessantemente novas e multidisciplinares perspectivas sobre o real, em textos nos quais predomina o estilo ensaístico e fragmentário. (...) A maioria dos autores e críticos afirma que há muitos, muitos Benjamins: o marxista, o judeu, o filósofo, o crítico literário, o modernista, o materialista messiânico. (...) Mas para outros, como Hannah Arendt, predomina em Benjamin o estilo fragmentário ensaístico, sendo que sua obra - composta em sua maior parte por discursos interrompidos, anotações, reflexões e aforismos - não podemos extrair uma teoria sistemática ou um conjunto unificado de teses. (...) O que Benjamin nos oferece é mais uma fragmentação sem síntese, em que a indeterminação, a incompletude, a plasticidade e a multiplicidade constituem elementos do pensamento filosófico. ${ }^{7}$

5 Ou seja, por mais que se pressuponha a possibilidade da existência de uma sistematicidade em Benjamin, esta possibilidade é sempre conduzida na estrutura da fragmentação. O que geralmente se faz é conectar e lincar, as "infinitas possibilidades de constelações" e expor uma ordem ao entendimento diversificado de sua filosofia. Todavia, há um problema neste proceder. A multiplicidade que a princípio seria 
importante e feliz na propagação e compreensão de sua filosofia, principalmente no favorecimento de seus mais importantes desdobramentos, acaba por criar nichos desconexos e monadológicos que subsistem por si só, tornando assim, um "universo de constelações mortas" que estão presentes na realidade, mas que não se comunicam, ou melhor, não iluminam a realidade da qual fazem parte. Afirmamos esta sentença não com a pretensão de rejeitar, reprovar ou ainda desqualificar os trabalhos feitos com base na sua vertente fragmentária que vem sendo apresentada sobre a filosofia benjaminiana, mas sim, afirmamos esta sentença com o objetivo de conectar estes trabalhos, estabelecendo assim, um vínculo necessário para a nossa justificativa enquanto reconhecimento de sua estrutura sistemática. Como esta conexão não era realizada ou pensada da forma como proporemos, ao mesmo tempo em que se pode ou se tenta expor a infinitude de sentidos provindos pela estrutura da linguagem benjaminiana, também acaba-se restringindo outras potencialidades e conectividades que podem ser expressas, na e pela linguagem. Ao invés de aproximar o ser para um processo reflexivo de compreensão da realidade, através de todos os signos e sentidos aos quais ele pode ser exposto, tal procedimento, o de se continuar ainda procedendo por um entendimento somente fragmentário da filosofia de Benjamin, afasta cada vez mais, ad infinitum, a(s) possibilidade(s) de revelar, através da própria História e da Experiência Vivida, a existência de sua estrutura sistêmica. Por isso, este procedimento restringe e limita a compreensão e a potencialidade de compreensão que o ser tem em captar a realidade, tal qual o Anjo da História, que é repelido do paraíso por uma tempestade que se aninha em suas asas e lhe lança para o futuro sem a possibilidade de retorno, como expõe Benjamin em seu texto Sobre o conceito de História8.

6 Por isso, sua estrutura sistemática, assim como sua própria definição de aura, está tão perto ao mesmo tempo que está distante, pois seu sistema se apresenta naquilo que Scholem descreve como "ciência secreta tão fina como a teia de aranha". E a esta tecitura estrutural denominamos aqui de sistema espectral da linguagem.

7 Segundo Gershom Scholem ${ }^{10}$, Walter Benjamin é necessariamente um filósofo da linguagem. $O$ próprio Benjamin confirma tal afirmação em seu Curriculum Vitae ${ }^{11}$, na qual explicita seus interesses pela filosofia da linguagem e estética. A reflexão estética teve maior repercussão por causa do seus principais trabalhos. Contudo é na linguagem e através da própria linguagem que Benjamin irá desenvolver sua estrutura filosófica e sistemática. Afinal, para que o seu sistema se sustente de maneira interconectada com os vários sentidos do dizer, do nomear, do propor, do afirmar, do pensar e do ser, ele se baseou numa herança sistemática do idealismo alemão, mas em uma específica herança desta época. De acordo com as principais investigações a respeito da filosofia benjaminiana, é de se notar que é quase imperceptível reconhecer a herança fichteana contida em seus estudos. Isto ocorreu, como já mencionamos anteriormente, porque ele foi escondendo estas influências. E na medida em que ele ia escondendo, ele apontava o direcionamento com o qual era comprovado estas influências. A diferença é que ele não quis, por algum motivo pessoal, revelar a fonte ${ }^{12}$. E, a maioria dos seus estudiosos, críticos, seguidores e até mesmo amigos pessoais, seguiram a via que Benjamin havia indicado. Um outro ponto necessário para este encobrimento, está em sua tese de doutoramento. Neste trabalho, Benjamin "marca e finda" suas influências do pensamento fichteano, abraçando diretamente os posicionamentos de Schlegel, Schelling e Novalis. Todos os seus leitores agarraram esta pista e seguiram no seu rastro. Necessariamente os mesmos passos. $O$ caminho indicado por Benjamin foi 
apresentado de maneira tão segura, que ele, conseguiu, ludibriar à todos, de forma induzida, fazendo com que não se reconhecesse as influências do pensamento de Fichte em sua filosofia, configurando assim, a principal justificativa a respeito da falta de uma sistematicidade em sua filosofia. Até mesmo um leitor experiente dos seus trabalhos, abraça as influências que Schlegel, Schelling e Novalis encabeçam ao final de sua tese de doutoramento. Por isso que, na medida que Benjamin amadurecia seu posicionamento filosófico, esta herança foi sendo escondida por um lado, e negligenciada ${ }^{13}$ por outro. Para darmos um exemplo de que a influência estrutural do seu sistema vinha sendo encoberta, na maioria das vezes quando buscamos compreender quais foram as principais influências do seu pensamento os seguintes nomes surgem: Descartes, Kant, Leibniz, Hammann, Hegel, Marx, Schelling, Novalis, Schlegel, Nietzsche, Cassirer, Ernest Bloch sem falar os poetas como Balzac, Baudelaire, Lessing, Goethe, Schiller entre outros como Einstein, Jung, Freud, Russell e Poincaré ${ }^{14}$. No entanto, quando estas influências aparecem, elas chegam com a propriedade que Benjamin dá e não como pontos interconectados do sistema que são. Ou seja, para que sua proposta sistemática pudesse passar incólume e de forma incógnita ele a codificou e encriptou a malha do seu sistema, tornando assim, a característica de fragmentação. A fragmentação da sua estrutura filosófica é a encriptação. As chaves desta encriptação se encontram na compreensão da existência de sua sistematicidade através dos seus textos, que são as cifras para a codificação e a desencriptação, e o reconhecimento de suas influência advindas da filosofia fichteana é o acesso a estrutura sistemática de Benjamin.

8 Outro ponto importante a se notar é que, se fôssemos organizar uma lista com a quantidade de livros que ele leu, que organizou numeradamente e guardou com lugar de destaque em sua biblioteca, provavelmente, teríamos por volta mais de dois mil livros, sem falar no que ele consumia enquanto literatura e que não fora listado. Tal fato, demonstra que Benjamin anotou em uma escala crescente a ordem dos livros que ele lia ${ }^{15}$. Mais uma amostra dessa variedade de temas que ele consumia é seu fascínio pela literatura infantil. Assim, a depender da área do conhecimento, diríamos que Benjamin lia tudo o que aparecia a sua frente. Em termos mais esdrúxulos, podemos afirmar que ele lia do "lixo ao luxo"16. Coisas triviais, simples e do cotidiano que chamavam sua atenção, como também posicionamentos existenciais profundos e de grande elaboração reflexiva, da mesma forma que mística.

9 Por isso, víamos e ainda vemos na maioria dos trabalhos que tratam de sua tese de doutoramento, ou da Obra do Drama Trágico Alemão o posicionamento filosófico de Fichte somente como via de acesso para Schlegel, Schelling e Novalis. Como geralmente nós seguíamos seus passos, o acesso aos pensadores do idealismos alemão desviavam a atenção para a principal fonte do seu pensamento. E é aqui onde nos deparamos com o erro. O não reconhecimento destas influências, seguindo a lógica de exposição apresentada pelo próprio Benjamin é o que nos afasta de tal relação. Afinal, as menções do pensamento de Fichte na Filosofia de Benjamin são aparentemente "pontuais, pequenas e quase imperceptíveis", mas, na maioria das vezes, contundentes.

10 A razão disto se dá porque Fichte só aparece, inicialmente, em seus estudos. Especificamente até metade de sua tese de doutoramento. Em seguida, no próprio desenvolvimento de sua tese, a incidência da presença de Fichte diminuí para abrir espaço para os posicionamentos posteriores a ele. Tal fato nos leva a seguinte questão: se o próprio Benjamin decidiu fazer desta forma, quem seríamos para contestá-lo? Nossa resposta imediata, somos críticos e críticos com base na própria crítica que 
Benjamin estrutura enquanto dispositivo ${ }^{17}$ de compreensão da codificação da realidade e do próprio ser. Justamente por seguir um posicionamento crítico é que devemos contestá-lo. Este é o papel da crítica. E como crítica em seu verdadeiro sentido, com uma proposta de esclarecimento e ampliação do próprio conhecimento apresentado pela filosofia de Benjamin. Por fim, o que iremos apresentar aqui é a reparação de uma falta histórica para com as influências do pensamento de Fichte na filosofia de Benjamin, da mesma forma como provar que o desdobramento da estrutura pensada por Fichte na Doutrina da Ciência e em alguns dos seus outros trabalhos possibilitou a constituição do sistema espectral da linguagem. Afinal de contas, se a maioria dos biógrafos ${ }^{18} \mathrm{e}$ dos compêndios a respeito da filosofia de Benjamin seguem a lógica apresentada pelo próprio autor, nosso papel é justamente profanar e romper com esta conexão, seguindo pelo método contrário, não como um ato leviano de plena discordância, mas de se seguir tanto o que a própria Susan Sontag expõe em suas palavras "A tarefa ética do [pesquisador contemporâneo] não é ser um criador, mas um destruidor" ${ }^{19}$ como também o que Benjamin faria. A meta é driblar o maneirismo empregado pelo próprio Benjamin no encobrimento do seu sistema filosófico da linguagem e acessá-lo livremente.

\section{II}

11 Inicialmente, em uma rápida contagem de palavras, procedendo pelo método de linguística de corpos, para mensurar a quantidade de vezes que o nome de Fichte está presente nos textos de Walter Benjamin, advindos da sua coleção de obras completas editados pela Surhkamp e disponíveis on-line pela Internet Archive ${ }^{20}$, podemos destacar que a maior frequência de aparecimento do nome de Fichte é em sua tese de doutoramento. É notável que a frequência de aparição do nome de Fichte vai diminuindo ao longo dos anos de desenvolvimento e amadurecimento do seu pensamento. Como ele prontamente tinha posto em funcionamento sua proposta espectral sistemática, desde seus primeiros escritos, consolidado com sua tese de doutoramento, e expandindo a abrangência dele em seus trabalhos futuros, Benjamin com todo o seu maneirismo ${ }^{21}$ foi se aproximando mais do que lhe apetecia investigar, encobrindo assim os rastros desta influência específica. É de se notar também que, mesmo este "distanciamento ilusório" teve uma eficácia enquanto uma estratégia de distração ${ }^{22}$ para firmamento do seu pensamento. A tabela abaixo apresenta em quais obras o nome de Fichte é citado, quantas vezes o nome dele aparece, quais as páginas desta referência e quais foram os anos de publicação destas obras.

\begin{tabular}{|l|l|l|l|l|}
\hline Livros - & $\begin{array}{lr}\text { Frequência de } \\
\text { aparição } r \\
\text { nome de Fichte } \\
\text { e }\end{array}$ \\
Gesammelte & suas \\
Schriften - & $\begin{array}{l}\text { declinações em } \\
\text { termos } \\
\text { Walter } \\
\text { Buantitativos } \\
\text { dentroramin. dos } \\
\text { textos enquanto } \\
\text { citações. }\end{array}$ & Páginas & $\begin{array}{l}\text { Textos em que aparecem os } \\
\text { nomes de Fichte }\end{array}$ & $\begin{array}{l}\text { Ano em que os } \\
\text { textos foram } \\
\text { escritos/ } \\
\text { desenvolvidos/ } \\
\text { publicados }\end{array}$ \\
\hline
\end{tabular}




\begin{tabular}{|c|c|c|c|c|}
\hline Band I & 80 & $\begin{array}{lr}18 ; 19 ; 20 ; \\
21 ; \quad 22 ; 23 ; \\
24 ; 25 ; 26 ; \\
27 ; \quad 28 ; 29 ; \\
30 ; 32 ; 33 ; \\
35 ; \quad 36 ; \\
38 ; 39 ; \quad 40 ; \\
51 ; 59 ; 60 ; \\
72 ; 91 ; 120 ; \\
290 ; \quad 805 ; \\
806 ; \quad 809 ; \\
1273 .\end{array}$ & $\begin{array}{l}\text { Der Begriff der Kunstkritik in der } \\
\text { deutschen Romantik/ Ursprung } \\
\text { des Deutschen Trauerspiels }\end{array}$ & $1919 / 1925$ \\
\hline Band II & 7 & $\begin{array}{ll}48 ; & 466 ; \\
589 ; & 809 ; \\
912 . & \end{array}$ & $\begin{array}{l}\text { FrüheArbeiten zur Bildungs - } \\
\text { Kulturkritik } \\
\text { Moralunterricht/ }\end{array}$ & $\begin{array}{l} \\
\\
1913 / 1937 / \\
1939 / 1929\end{array}$ \\
\hline Band III & 2 & 412. & $\begin{array}{l}\text { Kritiken und Rezensionen - Der } \\
\text { Eingetunkte Zauberstab }\end{array}$ & 1934 \\
\hline Band IV & 4 & $\begin{array}{l}207 ; \quad 208 ; \\
500 ; 877\end{array}$ & $\begin{array}{l}\text { Deutsche Menschen/ André Gidé } \\
\text { in Deustschland : Gespräch mit } \\
\text { dem Dichter/ Miszellen }\end{array}$ & 1928/ \\
\hline Band V & 3 & $\begin{array}{l}585 ; \quad 881 ; \\
939\end{array}$ & $\begin{array}{l}\text { Das Passage - Werke: N - } \\
\text { Erkenntinistheorietisches } \\
\text { Theorie des Fortschritts/ a- } \\
\text { Aufzeichnungen und Materialien } \\
\text { soziale Bewegung/ g- Die Börse } \\
\text { Wirtschaftsgeschichte }\end{array}$ & $1927-1940$ \\
\hline Band VI & - & - & - & - \\
\hline Band VII & 3 & $\begin{array}{l}442 ; \quad 623 ; \\
903\end{array}$ & 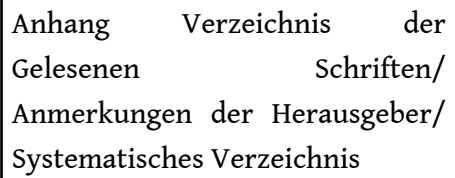 & 1940 \\
\hline $\begin{array}{l}\text { Total de } \\
\text { frequência } \\
\text { do nome de } \\
\text { Fichte }\end{array}$ & 99 & & & \\
\hline
\end{tabular}

(TABELA 1)

12 Percebamos que mesmo com a diminuição da frequência de aparição do nome de Fichte, ele ainda é mencionado. Ou seja, ao longo de suas obras, Benjamin não cita mais 
Fichte por quantidade de referências, mas sim por qualidade e reconhecimento de suas reflexões. Por exemplo, em seu trabalho sobre Origem do Drama Barroco Alemão temos a seguinte citação: "Schopenhauer entendeu a tragédia como drama trágico. Entre os grandes metafísicos alemães depois de Fichte ele terá provavelmente sido aquele que menos se aproximou da compreensão do drama grego" ${ }^{23}$. 0 ano desta citação, é 1925. Mesmo que durante toda a obra do Origem do Drama Trágico Alemão, o nome de Fichte seja mencionado esta única vez, Benjamin ainda tem um grande reconhecimento por ele enquanto um importante metafísico e legitima, provavelmente em seu íntimo, a importância dele para a sua própria filosofia.

13 Outro exemplo que destacamos aqui, para que percebamos, é que a frequência diminuiu, mas a importância aumentou, pois existe mais uma referência na sua obra As Passagens. Neste universo infinito de constelações de sentido, o nome de Fichte aparece em três momentos. No primeiro momento, sua referência aparece na letra $N$ - Teoria do Conhecimento, Teoria do Progresso - N 6a,1. O nome de Fichte aparece em um recorte que Benjamin faz de uma carta de Engels a Mehring, de 14 de julho de 1893.

É sobretudo esta aparência de uma história autônoma das constituições de Estado, dos sistemas jurídicos e das representações ideológicas em cada domínio particular que ofusca a maioria das pessoas. Quando Lutero e Calvino 'superam' a religião católica oficial, quando Hegel 'supera' Fichte e Kant, e Rousseau, com seu Contrato Social, indiretamente 'supera' o constitucional Montesquieu, trata-se de um processo que, mantendo-se no âmbito da teologia, da filosofia, da ciência política, representa uma etapa na história destes domínios do pensamento, sem ultrapassar a esfera do pensamento. $\mathrm{E}$ desde que se somou a isso a ilusão burguesa relativa ao caráter eterno e definitivo da produção capitalista, até mesmo a superação dos mercantilistas pelos fisiocratas e Adam Smith é considerada uma mera vitória do pensamento - não o reflexo intelectual de fatos econômicos transformados, mas a visão correta, finalmente conquistada, de condições reais, sempre presentes em todos os lugares. ${ }^{24}$

14 Como podemos visualizar no trecho citado acima, a palavra supera aparece entre aspas. Duas interpretações podem ser obtidas aqui. Em um primeiro momento a superação da qual Engels menciona se deu de fato, mostrando assim, que os posicionamentos filosóficos citados realmente foram ultrapassados pelo novo pensar fora do idealismo e da idealização das questões econômicas expostas pelas teorias das quais Engels critica e expõe em sua época. Ou, em uma segunda análise, os posicionamentos filosóficos citados não foram superados, reforçando assim, que todos os pensadores citados apresentam ainda questões importantes a serem investigadas e que eles ainda trazem pontos necessários a serem desdobrados. Como nosso objetivo não é nos encaminhar pela investigação se de fato esta superação nos termos aos quais Engels expressa se comprovaram adequadamente, nos limitaremos a expor que, a menção ao nome de Fichte nesta citação entra apenas como mais uma referência ao seu nome contabilizado pela linguística de corpus da mesma forma que respalda sua importância comprovada pela própria História da Filosofia.

15 A segunda aparição do nome de Fichte no texto As Passagens se apresenta numa reflexão bastante curiosa. Hegel e Fichte expressam suas impressões a respeito do novo continente, a América, a - Movimento Social - 14a 3.

A América na filosofia de Hegel: "Hegel (...) não elaborou uma expressão direta para a consciência do fim de uma época da história, mas uma expressão indireta. Ele a manifesta pelo fato de pensar - lançando um olhar sobre o passado, na 'velhice do espírito', ao mesmo tempo que procura uma descoberta possível no domínio do 
espírito - sem revelar expressamente o conhecimento desta descoberta. As raras indicações sobre a América, que já nessa época aparecia como o futuro país da liberdade". [Nota: A. Ruge, Aus früherer Zeit, in vol IV, p. 72 a 84: "Fichte já pensara em emigrar para a América, na ocasião da derrocada da velha Europa; carta a sua mulher 28 de maio de 1807"] "e sobre o mundo eslavo, visavam a possibilidade de o espírito universal emigrar para fora da Europa, a fim de preparar novos protagonistas do princípio do espírito (...) que se completou com Hegel. ${ }^{25}$

16 Neste ponto, vemos os dois teóricos idealistas preocupados com os rumos políticos da Europa, mas com uma certa ênfase em se saber onde eles poderiam dar continuidade aos seus trabalhos. Afinal, se o seu reduto de morada viesse a colapsar eles deveriam pensar numa estratégia de fuga para favorecerem a permanência e a continuidade de suas ideias.

17 E por fim, a última referência que o nome de Fichte aparece é em uma alusão de como funciona o esquema filosófico do idealismos alemão. $g$ - A Bolsa de Valores, História Econômica-g1 2 .

Um esquema extraído da obra de Edgar Quinet. De la Révolution et de la Philosophie: "O desenvolvimento da filosofia alemã: (...) uma espécie de teoria da revolução francesa. Kant é a Constituinte; Fichte, a Convenção; Schelling, o Império (através do respeito pela força física); e Hegel parece ser para ele a Restauração e a Santa Aliança. "Schimdt - Weißenfels, Poutraits auf Frankreich, Berlim 1881, p. 120. (Edgard Quinet und der französische Nationalhaß - "Edgar Quinet e o ódio nacional francês). ${ }^{26}$

18 Se nestes breves momentos, Fichte aparece em três formas de análises distintas, ele não aparece por acaso. Mesmo sendo mencionado indiretamente por outros teóricos, faz se notar em três diferentes momentos que ele ainda tem uma importância filosófica relevante para Benjamin. Mesmo ele tendo sido escondido enquanto influência. Contudo, o caminho que devemos seguir não nos remete aos trabalhos maduros de Benjamin, mas sim, aos trabalhos de sua juventude. Especificamente, existem alguns trabalhos que foram base para a constituição do seu sistema. Mesmo Benjamin tendo nunca mencionado-os em seus escritos, algumas passagens de seus textos, reinterpretados por ele, provam tal influência. Dito de outra forma, a similaridade dos discursos, os objetivos investigados e os desdobramentos obtidos são frutíferos. Para Fichte, porque amplia o leque epistemológico de sua filosofia, mostrando não só o alcance, mas também confirmando sua proposta incessante e evolutiva do seu sistema. Para Benjamin, sustenta todo o escopo que sua filosofia tem, articula todos os saberes dos quais ele investigou, comprova a multiplicidade de sentidos que podem expressar sobre o ser na/pela linguagem, proporciona o desdobramento de um entendimento a respeito de uma estética fichteana e expõe um novo olhar que devemos ter sobre o papel da linguagem em sua filosofia.

\section{III}

19 O entendimento e o esclarecimento que iremos ter a respeito do funcionamento da estruturação do sistema benjaminiano nos conduz necessariamente aos seus textos de juventude. Entretanto, para chegarmos até seus textos de juventude seguiremos por um prisma distinto das vias tradicionais. Como as influências do pensamento de Benjamin, já são de proporções globais, indicar o caminhos que seguiremos é necessário como instrumentação metodológica. 
20 Seja na Bélgica, na França, na Alemanha, na Inglaterra, nos Estados Unidos, na Espanha, em Portugal e até mesmo no Brasil, cada uma destas localidades receberam as obras de Benjamin numa determinada perspectiva. As multiplicidades de entendimentos, não inviabilizam a sua completude, mas podem gerar dissonâncias perceptíveis que somam e agregam ao todo. Tomaremos como recorte neste momento o exemplo da receptividade apresentada no Brasil ${ }^{27}$.

21 Sua chegada aos trópicos, seguiu por um direcionamento mais marxista, estético, político e literário ${ }^{28}$. Este direcionamento se deu pelo momento histórico que o país viveu. Seu o primeiro texto traduzido para o português do Brasil foi A obra de arte na era da sua reprodutibilidade técnica, publicando em $1959^{29}$ antes da instauração da Ditadura Militar $^{30}$ no país. Após esta data, uma nova publicação do mesmo texto, traduzida por um outro pesquisador foi publicada em $1968^{31}$, neste momento agora, no já instaurado regime militar. Neste período, havia ainda o problema no que diz respeito as questões editoriais e gráficas no Brasil, que "escolhiam"32 o que era tido como pertinente e importante a se traduzir e apresentar para o leitor brasileiro. Tais procedimentos acarretaram, e de certa forma ainda acarretam, um atraso na tradução de suas outras obras, resultando em um direcionamento, em geral, bem específico. Não há disponibilidade de todas as obras do Benjamin, até o presente momento, para a língua portuguesa do Brasil. Se formos complementar esta falta com as traduções para o português de Portugal, tendo a Internet como um meio que facilitou os caminhos, mas não desbloqueou as vias, ainda assim, suas obras não alcançam sua completude. Primeiramente porque os mesmos textos que foram publicados no Brasil são os mesmos textos que foram publicados em Portugal e vice-versa. Para não tornar esta afirmação muito dura, a distinção dos textos de Benjamin entre os dois países se dá na exposição de traduções livres, feitas por pesquisadores em revistas específicas da área que geralmente são apresentadas de formas independentes e não reunidas em volumes ou livros específicos de Walter Benjamin..$^{33}$ Ou seja, ainda é necessário reparar esta dívida histórica que se tem com a não completude das traduções das obras de Benjamin para o português em geral, e em específico para o português do Brasil.

22 Um outro ponto importante que constatamos a respeito da receptividade das obras de Benjamin no Brasil, e no mundo como um todo, é que o autor nos conduz a direcionamentos a respeito da mística judaica. Estes posicionamentos se entrecruzam e se opõe na medida em que avançamos no entendimento de Filosofia, mas é uma peça chave para o entendimento do seus sistema filosófico. Mesmo Scholem, atestando que ainda faltara muito estudo e dedicação do próprio Benjamin sobre as questões judaicas, podemos afirmar que, se não relacionarmos as questões estudadas por Benjamin da mística judaica a sua proposta filosófica de linguagem, não será fácil compreender os resultados da estruturação do seu sistema espectral da linguagem. Um exemplo de caráter comprovável sobre este ponto nevrálgico em sua filosofia por assim dizer, e material, é a aplicação do conceito de Golem $^{34}$ existente em sua filosofia como a materialidade da palavra enquanto resultado concreto de suas ideias místicas.

23 Benjamin em suas conversas com Scholem, absorvia o máximo que podia sobre as questões da mística judaica. Nestas discussões, ambos tratavam de variados temas e sobre diversos posicionamentos do judeu e do judaísmo. Inclusive, estas conversas sempre geraram debates bastante prolíficos para ambos. Benjamin conhecia as discussões judaicas apresentadas por Martin Buber e Ernest Bloch, na qual, em suas cartas à Scholem, as debate criticamente expondo os problemas existentes que ambos 
os posicionamentos apresentavam. Contudo, uma obra que foi fundamental para a formação mística judaica de Benjamin, foi o livro A Estrela da Redenção, de Franz Rosenzweig. Benjamin escreve a Scholem: "É possível que, algum dia, lhe peça para mandar-me Der Stern der Erlösung - mas esperarei para que você não o faça desnecessariamente" ${ }^{35}$. Todavia, posteriormente, tomamos o conhecimento como atesta Scholem que Benjamin o leu e o leu como "um leitor apaixonado da Estrela da Redenção" ${ }^{36}$. De acordo com Scholem, este é "o trabalho mais original da teologia judaica de nossa geração" ${ }^{37}$. Porém, nos resguardamos e suspendemos nossos juízos sobre o tema neste presente momento, por aspectos mais pragmáticos e objetivos a se seguir. Afinal, existe na filosofia de Walter Benjamin um sistema que precisa ser decodificado ${ }^{38}$.

\section{IV}

24 De acordo com Wolfram Eilenberger ${ }^{39}$ em seu mais recente trabalho Tempo de Magos, o autor apresenta de forma contundente o quão importante é a perspectiva de Benjamin a respeito da linguagem, da mesma forma como incita sua investigação. Ele reconhece que, ao lado de Heidegger, Cassirer e Wittgenstein, Benjamin se tornou um dos principais pensadores do início do Século XX. A razão deste destaque se encontra na própria problemática da linguagem. Cada um a sua maneira, expôs como o ser pode pensar e compreender a realidade através da linguagem. Necessariamente outros fatores importantes contribuíram para tal avanço desta reflexão filosófica, pois com o fim de um período sistemático da filosofia, encerrado especificamente com a morte de Hegel, a exposição e evolução da própria Ciência ${ }^{40}$ e pela própria reviravolta linguísticopragmática $^{41}$, resultaram no firmamento deste novo paradigma. No caso de Benjamin, tal justificativa remonta não só um período específico de sua produtividade, mas como um dos seus períodos mais importantes, do qual, proporcionou todos os últimos desdobramentos reflexivos apresentados por ele até 1940. Eilenberger destaca que, entre 1919 e 1929, Benjamin seguiu, a sua própria maneira, uma importante discussão a respeito da linguagem, em paralelo ao que se estavam discutindo na época. Junto com os outros magos, Benjamin não só se preocupou com os rumos da Filosofia, do Conhecimento, das Artes, mas sim com os rumos da própria problemática existencial do ser, enquanto sujeito consciente de ações e sentidos que ele próprio atribui a realidade. Esta preocupação também ganha um olhar e uma reflexão adicional de maior proporção, porque após o desenvolvimento da técnica ${ }^{42} \mathrm{e}$ dos seus métodos de reprodução, o ser não será mais o mesmo.

Se para Wittgenstein, em específico o primeiro Wittgenstein, em sua tese 1.1 "O mundo é a totalidade dos fatos, não das coisas" ${ }^{43}$, Benjamin afirma em uma outra perspectiva que "A multiplicidade nomeada é finita" ${ }^{44}$ para destacar não só uma consonância com as palavras de Wittgenstein, mas apontar o erro que o Romantismo teve em relação ao conhecimento da própria verdade. A importância de perceber o conhecimento da própria verdade enquanto fenômeno sem torná-la objeto de uma idealização metafísica transcendental impossível, coaduna-se na filosofia de Benjamin com a realização factual do conhecimento da realidade pelo próprio ser numa experiência histórica, temporal e concreta que será vivida e vivenciada pelo próprio sujeito. Isto se justifica, porque nesta estrutura de conhecimento, na realização concreta do fenômeno, o ser poderá atribuir a si, por meio de um processo reflexivo na/pela própria existência, como ele referenciará o sentido dela. Ou seja, somente com o reconhecimento de si enquanto 
um sujeito cognoscente é que o ser poderá compreender o sentido da existência em referência as codificações que eu compreendo e decodifico da realidade na/pela linguagem. Além disso, é possível notar que Benjamin segue em paralelo com o primeiro Wittgenstein, preocupado com a problemática da nomeação das coisas, pois ele já havia percebido as restrições existentes sobre a ação de nomeá-las. Por isso, sua preocupação em tentar transpor a restrição que a linguagem tem em decodificar a realidade por completo, o conduziu a problemática aporética deixada por Platão ${ }^{45}$, quando ele escreve em 1916 Sobre a linguagem em geral e sobre a linguagem do Homem. No entanto, diferentemente de Platão, Benjamin consegue vislumbra e propor uma solução para a aporia platônica através da História. Para transpor o problema desta nãodeterminação através do nome das coisas da realidade, é necessário incluir uma categoria de autonomia durante o próprio processo de reflexão na/pela linguagem. Afinal, somente compreendendo o sentido dos nomes em seu tempo histórico é que a ação de nomear as coisas, tal qual a de se criar e gerar conhecimento, poderá proporcionar ao ser as cifras e as chaves para desencriptar a realidade. Este posicionamento proporciona a Benjamin, um avanço gigantesco na discussão de linguagem, da mesma forma como o próprio Wittgenstein seguiu, a respeito do problema do sentido que a linguagem irá expressar. Afinal, para que o entendimento dos nomes das coisas exponha o seu sentido na História da Filosofia, é necessário transcender a barreira imposta somente pelos fatos (primeiro Wittgenstein), ampliando assim a possibilidade de se conhecer a realidade através do sentido que a linguagem expressa (segundo Wittgenstein) ${ }^{46}$ e o salto evolutivo da aporia platônica. Sem a realização concreta da existência na História a possibilidade de compreensão idealista continuaria sendo regida pelas propostas metafísicas do Século XIX. E se esta lógica fosse seguida, acabaríamos esbarrando nos obstáculos já apresentados pela Reviravolta Linguístico-Pragmática. Ou seja, haveria a estagnação da reflexão e uma não ascensão do ser em compreender sua própria realidade, pois a reflexão sobre técnica ${ }^{47}$ é quem demarca também o avanço em direção a superação das propostas idealistas sistemáticas fechadas ${ }^{48}$. Dito de outra forma, o que Benjamin faz, quando se trata de compreender a realidade através de sua proposta filosófica e espectral da linguagem é simplesmente transpor o fenômeno que se restringe no nível das nomeações para alcançarmos a compreensão no nível dos sentidos. Quando compreende-se os sentidos da realidade a compreensão das suas ações enquanto movimento dialético derivado do Tathandlung ${ }^{49}$ fichteano proporciona a decodificação e o esclarecimento estético necessário para vivenciar a realidade. Esta transposição é a base para entender o funcionamento do sistema espectral benjaminiano.

Assim, como a maioria dos sistemas idealistas ou ainda, como a maioria dos sistemas existentes na realidade, eles são compostos de parte e estas partes geram o fluxo do seu movimento. $O$ sistema benjaminiano não é diferente disso e funciona com três forças motrizes. São elas: o código (linguagem/mundo/malha da realidade ${ }^{50}$ ), a encriptação e a desencriptação (tradução) e cyberdaimon (crítica). Estas três categorias movimentam o fluxo do sistema, enquanto organicidade. $O$ resultado desta organicidade é a criação de imagens enquanto constructos descritivos de/dos sentidos da realidade e postos enquanto expositores nominativos que falam sobre o ser e sobre a realidade. Então temos:

27 O Código é aquilo que estrutura a tecitura da realidade; 
28 A encriptação e a desencriptação é o processo de codificação e descodificação da malha da realidade. No processo de leitura da realidade existem dois dispositivos que possibilitam a exposição do constructo imagético da realidade, a chave e a cifra; Cyberdaimon é aquele que compreende o processo de codificação da realidade, que consegue encriptá-la e desencriptá-la modelando seu conhecimento e entendimento a respeito dela com o objetivo de expandi-la ao longo da história, cujo resultado pode vir a ser consolidado em um constructo ${ }^{51}$.

30 Contudo, a principal pergunta que devemos responder aqui é: de onde provem a estrutura espectral da linguagem?

31 De maneira pragmática a resposta é: de suas influências da filosofia de Fichte. Por quê? Porque a proposta sistemática de Fichte é aberta, ou seja, ela tem em seu mecanismo interno um desenvolvimento transcendental ad infinitum, que resulta numa constante expansão do próprio conhecimento do ser e da própria realidade. Obviamente como se trata de um processo de/em expansão, não é necessário dimensionar seu início e nem seu fim, já que nos encontramos inseridos no mesmo processo. O que nos cabe aqui é decifrar a linguagem da realidade. E como Benjamin percebeu esta estrutura, ele pôde compor sua proposta. Afinal, como se trata de um sistema na qual ele construiu com base na linguagem, ele já deixou articulado aquilo o que mais tarde ele solicitará de Marx em sua XIV tese em seu texto Sobre o Conceito de História. Benjamin recorre à sua leitura de Marx e nos diz:

A história é objeto de uma construção cujo lugar não é o tempo homogêneo e vazio, mas um tempo saturado de "agoras". Assim, a Roma antiga era para Robespierre um passado carregado de "agoras", que ele fez explodir do continuum da história. A Revolução Francesa se via como uma Roma ressurreta. Ela citava a Roma antiga como a moda cita um vestuário antigo. A moda tem um faro para o atual, onde quer que ele esteja na folhagem do antigamente. Ela é um salto de tigre em direção ao passado. Somente, ele se dá numa arena comandada pela classe dominante. 0 mesmo salto, sob o livre céu da história, é o salto dialético da Revolução, como o concebeu Marx. ${ }^{52}$

32 É neste salto do tigre em direção ao passado que iremos montar para compreender como ele montou sua proposta.

Manfred Frank, em seu livro Auswege aus dem Deutschen Idealismus inicia com a seguinte passagem o seu capítulo Filosofia como <<aproximação infinita»>. Consideração a partir da $<<$ constelação $>>$ do primeiro romantismo alemão:

(...) o primeiro romantismo, por menos filosófico, é desconhecido por excelência nos arquivos da História das Ideias, e não só nos da oficial. Esta situação não se deve exclusivamente a que fontes, como o sistema esboçado por Hölderlin em Juízo e Ser (Maio de 1795), os Estudos sobre Fichte de Friedrich von Hardenberg (de Setembro de 1795 até Julho de 1796), os Anos de aprendizagem filosófica de Friedrich Schlegel (desde Agosto de 1796), foram encontrados e/o criticamente editados tão somente desde algumas décadas; faltava, sobre tudo, uma perspectiva sistemática destes documentos, transmitidos em sua maioria de forma fragmentária. Somente a <<análises de constelações»> Konstellationsforchung fundado por Dieter Henrich e seus discípulos foi modificada radicalmente a situação da investigação nos anos 90 (cf. Muslow/Stamm 2005). Este método hermenêutico pode se caracterizar da seguinte maneira: trata de seguir os passos de paulatina elaboração de pensamentos 
e pressuposições filosóficas de numerosos autores a partir do intercâmbio de ideias que poderia ter dado entre eles dentro de um espaço de tempo rico em acontecimentos relevantes. Neste caso, deste período de tempo, extraordinariamente frutífero filosoficamente falando, transcorrido em Jena entre a publicação do Ensaio de uma nova teoria da capacidade humana de representação (1789) de Carl Leonhard Reinhold e as primeiras reações significativas antes da exposição de Johann Gottlieb Fichte de sua Doutrina da Ciência (1794/95; para isso, Frank 1998). Através deste método de análise de constelações existe a possibilidade de completar, como em um puzzle, pensamentos de um autor, transmitidos de forma fragmentária, através de pensamentos de outro autor (até o momento desconhecidos ou desamparado), cuja formação ou convicções foram (ou poderiam seguir) uma linha muito similar. Felizmente, este é o caso de Hölderlin, Friedrich von Hardenberg e Friedrich Schlegel, que desde o começo de 1790 estudaram diretamente com Reinhold ou estiveram através de um terceiro (Niethammer), da situação da discussão dentro do círculo de estudantes formado em torno dele. Um conhecimento minucioso da referida discussão é especialmente importante para nós, já que alcança contrapor-se a imagem que de fato na História da Filosofia do processo de reelaboração da filosofia kantiana e do surgimento do idealismos alemão. Esta discussão começou com a conviç̧ão de Reinhold segundo a qual, a filosofia de Kant lhe faltava um princípio supremo a partir do que se poderia fazer compreensível e uniria sua desmembração, não somente nos princípios irredutíveis entre si, mas também das três Críticas. No entanto, entre os estudantes de Reinhold logo começou a surgir dúvidas em torno deste programa fundamentalista; dúvidas que logo desembocariam em uma tentativa de Fichte de superar os princípios filosóficos de Reinhold. De certo modo, aquelas posições contrárias a tentativa fundamentalista expressam fidelidade a Kant e mostram um caminho de como poderia ter sido evitadas as consequências de um retorno a metafísica; caminho que logo seguiria, com grande repercussão o Idealismo Alemão. 53

34 Nesta passagem, um pouco longa, mas de extrema importância, identificamos dois termos importantes dos quais Benjamin estrutura sua proposta espectral da linguagem: constelações e fragmentária.

Através deste método de análise de constelações, existe a possibilidade de completar, como em um puzzle, pensamentos de um autor, transmitidos de forma fragmentária, através de pensamentos de outro autor, (...) cuja formação ou convicção foram (...) uma linha muito similar ${ }^{54}$.

35 Completar como em um puzzle, ou seja, como um jogo que proporciona ao ser uma infinita liberdade de sentidos. Sentidos estes determinados pela multiplicidade e multinaturalidade ${ }^{55}$ das experiências do ser inseridas na História e da qual se conectam através dos modos de dizer de si e do dizer do outro na/pela linguagem. Benjamin aqui, extraí o fluxo e a fluidez que movimenta o seu sistema. Através deste jogo ele não só viabiliza uma nova perspectiva a respeito dos questionamentos do ser, mas também antecipa uma metodologia inteira, que servirá de base fundamental para a Antropologia Estruturalista de Claude Lévi-Strauss, a bricolagem ${ }^{56}$.

36 Apesar de sua metodologia se manter quase que por completo invisível, translúcida, ou ainda de forma fantasmagórica, esta se encontra aberta, acessível, livre e aglutinável em seus processos. Ou seja, por mais que se projete sua imagem ${ }^{57}$ de fragmentária, por trás desta mera aparência, há uma sistematização necessária.

37 Assim, compreendendo este percurso percorrido até aqui é essencial reconhecer alguns pontos necessários para avançarmos mais na presente investigação. De um lado, já sabemos que há toda uma referenciação nos escritos Benjamin dos textos de 
Hölderlin, Kant, Hegel, Schlegel, Schelling, Novalis e companhia. Sabemos também que estes autores, sejam eles anteriores ou posteriores a Kant, enquanto influências em sua pensamento, foram embebidos e maturados por Benjamin, para que ele pudesse firmar seu posicionamento filosófico. Cada uma destas influências seguiram seu caminho como atesta o próprio Manfred Frank, como a necessidade que o Idealismo Alemão encontrou para se firmar explicitado em seu livro. O que não compreendemos é que há uma contínua tentativa e sustentação de sempre se escantear o pensamento de Fichte destas relações. Mesmo os posicionamentos contra o pensamento de Fichte expostos por seus críticos mais ferozes como Schlegel, Schelling e até mesmo o posicionamento do próprio $\mathrm{Kant}^{58}$, geralmente, entram mais em evidência enquanto influência no pensamento de Benjamin do que o pensamento de Fichte. Até onde se segue as influências de Fichte permanecem até a metade de sua tese de doutoramento, onde Benjamin opta por "abandonar" estas influências por ter "seguido" ${ }^{59}$ assim pela proposta de Schlegel, Schelling e Novalis. Por quê isto procedeu até agora desta maneira? Não compreendemos completamente. Levantamos a hipótese de que os estudiosos, críticos e seguidores do pensamento benjaminiano não alcançaram la ilustración que Benjamin havia deixado translucido em seus escritos. A grande maioria preferiu usar de um olhar míope devido a dificuldade de se focalizar fluxos em movimento ${ }^{60}$.

38 Deste modo, é necessário escavarmos mais a fundo para remontar este traço de influências tão importantes à Benjamin contidos em seus escritos de juventude. Seus textos não publicados e publicados ${ }^{61}$. Somente assim, será possível pensar um novo entendimento de sua filosofia e dos seus textos.

39 O salto do tigre para o passado foi dado. Mesmo nós tendo chegado ao ponto de demarcação da estruturação do seu pensamento, através dos pontos apresentados por Manfred Frank, a respeito de como se estruturou o primeiro romantismo alemão, e da qual ele seguirá nos desdobramentos até uma estruturação com base no pensamento de Novalis, é com Fichte que devemos nos encontrar. Fato este, necessário, pois é um encontro mais que possível. É uma encontro necessário. Enquanto Benjamin teve que fazer sua tese de doutoramento, provavelmente ele recorreu de outras fontes tão importantes quanto a própria Doutrina da Ciência. E de antemão, já indicaremos a trajetória. Benjamin com certeza, e nos arriscamos com esta afirmativa, leu Sobre a Capacidade Linguística e a Origem da Língua ${ }^{62}$ e Sobre o Espírito e a Letra: numa série de cartas. Por quê afirmamos isto? Porque suas influências ocultas de Fichte estão nestes dois importantes textos. Por isso, nosso próximo rastro é seguir e analisar de maneira técnica estes dois trabalhos de Fichte, comparando-os com alguns dos textos de juventude como Dois poemas sobre Hölderlin, O significado da linguagem no Drama Barroco e na Tragédia, Sobre o Programa da Filosofia Vindoura, O Arco-íris, Destino e Caráter, Sobre a linguagem em geral e sobre a linguagem do homem ${ }^{63}$, para posteriormente comprovarmos os desdobramentos das influências fichteanas em sua obra mais famosa $A$ obra de arte da nera da reprodutibilidade técnica ${ }^{64}$

\section{Referências Bibliográficas}

AGAMBEN, Giorgio. 2009. O que é um dispositivo, in O que é contemporâneo? e outros ensaios. Chapecó - SC: Argos.

BARRENTO, João. 2013. Limiares sobre Walter Benjamin. Florianópolis: Editora UFSC. 
BENJAMIN, Walter. 1991. Gesammelte Schriften Bd. 1 - Bd. 6. Frankfurt am Main: Suhrkamp Verlag.

BENJAMIN, Walter. 1999. Gesammelte Briefe Bd. 5 - Frankfurt am Main: Suhrkamp Verlag.

BENJAMIN, Walter. 2012. Das Kunstwerk im Zeitalter im seiner technischen Reproduziertbarketi. Suhrkamp Verlag.

BENJAMIN, Walter. Franz Kafka. 1987. A propósito do décimo aniversário de sua morte, in Magia e técnica, arte e política. São Paulo: Editora Brasiliense.

BENJAMIN, Walter. 2002. O conceito de crítica de arte no romantismo alemão. São Paulo: Iluminuras.

BENJAMIN, Walter. 2010. Experiência e Pobreza, in O Anjo da História. Lisboa - Portugal: Assírio \& Alvim.

BENJAMIN, 2011. Origem do Drama Trágico Alemão. Belo Horizonte: Autêntica.

BENJAMIN, W. 2011. Curriculum Vitae Dr. Walter Benjamin, in Origem do Drama Trágico Alemão. Belo Horizonte: Autêntica

BENJAMIN, Walter. 2011. As afinidades eletivas de Goethe. São Paulo: Editora 34.

BENJMAIN, Walter. Sobre o conceito de História, in Lisboa - Portugal: Assírio \& Alvim.

BENJAMIN, Walter. 2009. As passagens. Belo Horizonte: Editora UFMG/ São Paulo: Imprensa Oficial do Estado de São Paulo.

BENJAMIN, W. 2013. Escavar e Recordar, in Sobre o haxixe e outras drogas. Belo Horizonte: Autêntica

BENJAMIN, W. 2017. A obra de arte na era da reprodutibilidade técnica. Belo Horizonte: Autêntica.

BENJAMIN, Walter. 2018. Sobre a linguagem em geral e sobre a linguagem do homem. Belo Horizonte: Autêntica.

CAYGILL, H.; COLES, A.; KLIMOWSKI, A. 2014. Walter Benjamin a graphic guide. Icon Books Ltd.

CHALMERS, Alan F. 1993. O que é ciência afinal? São Paulo: Editora Brasiliense.

DERROITTE, Élise. 2018. Critic is a Philosophy of the Spirit: Comparing Benjamin and Fichte's Programmes for the Comming Philosophy. "Critique is a Philosophy of the Spirit ", Anthropology \& Materialism [Online], Special Issue / I / 2017, Online since 02 March 2017, connection on 04 December 2018. URL : http:// journals.openedition.org/am/731 ; DOI : 10.4000/am.731.

EILENBERGER, Wolfram. 2019. Tiempo de Magos. Madrid: Taurus.

FINDLER, Richard. Was Fichte Heidegger's political Fürsprecher? Fichte and Heidegger on language. 1999. Symposium, Volume 3, Issue 2, Fall 1999. URL: https://www.pdcnet.org/ symposium/content/symposium_1999_0003_0002_0169_0183； DOI: 10.5840/ symposium19993218.

61 FRANK, Manfred. 2015. Filosofia como <<aproximación infinita >> Consideración a partir de la <constelación>> del primer romantismo alemán, in Auswege aus dem Deutschen Idealismus. Frankfurt am Main: Suhrkamp.

62 GASPARI, Elio. 2002. A ditadura envergonhada. volume 1. Coleção As Ilusões Armadas, São Paulo: Companhia das Letras. 

pid=S0120-00622007000100008\&script=sci_arttext $>>$. NASCIMENTO, E. V. M. 2017. Processos, tradução e edição: por que e discutir a estrutura do texto A obra de arte na era da sua reprodutibilidade técnica de Walter Benjamin no Século XXI?. Monografia, UFPB - Campus IV. KANT, I. 2007. La declaración pública de Kant contra Fichte. Trad. F. Moledo, IDEAS Y
VALORES, 56/133. Disponível em:« http://www.scielo.org.co/scielo.php? Século XXI?. Monografia, UFP - Campus IV. OLIVEIRA, Manfredo Araújo. 2015.
contemporânea. São Paulo: Loyola.

PRESSLER, Gunter K. 2006. Benjamin Brasil. São Paulo: Annablume.

\section{Revista USP № 15 Dossiê Walter Benjamin de 1992.}

ROCHLITZ, Rainer. 2003. O desencantamento da arte. Bauru - SP: EDUSC.

6 SCHOLEM, Gershom. 1989. Walter Benjamin: a história de uma amizade. São Paulo: Perspectiva. SCHOLEM, Gershom. 1994. O Golem, Benjamin, Buber e outros justos: judaica I. São Paulo: Perspectiva. SONTAG, Susan. 1986. Sob o signo de Saturno. São Paulo: L\&PM Editores. VIVEIROS DE CASTRO, Eduardo. 2015. Metafísicas canibais. São Paulo: Cosacnaify N-1. WITTE, Bernd. 2017. Walter Benjamin uma biografia. Trad. Romero de Freitas. Belo Horizonte: Autêntica.

\section{NOTAS}

1. Apresento aqui uma releitura do que Benjamin propõe na introdução da terceira parte do seu texto sobre Alegoria e Drama Trágico. “Toda reflexão, mesmo a mais ambiciosa, desenvolvida até agora, com base num método aqui e ali talvez ainda vago, ainda impregnado de historicismo cultural, converge, de fato, na categoria do alegórico e condensa-se no drama trágico ao nível da 
ideia. Só por isso a exposição pode, e deve, insistir na estrutura alegórica desta forma, porque só graças a ela o drama trágico pode assimilar, como substância própria, os materiais que são oferecidos pelas condições históricas da época". BENJAMIN, 2011. Origem do Drama Trágico Alemão. p. 233.

2. Os dois conceitos expostos Erinnerung e das Erlebt, estão presentes em seu texto Escavar e Recordar, da qual Benjamin inicia esta reflexão com a seguinte afirmação: “A Linguagem fez-nos perceber, de forma inconfundível como a memória [Gedächtnis] não é um instrumento, mas um meio, para a exploração do passado. É o meio através do qual chegamos ao vivido [das Erlebte]. Do mesmo modo que a terra é o meio no qual estão soterradas as cidades antigas". BENJAMIN, W. 2013. Escavar e Recordar, in Sobre o haxixe e outras drogas, p. 101.

3. DERROITTE, Élise. 2018. Critic is a Philosophy of the Spirit: Comparing Benjamin and Fichte's Programmes for the Comming Philosophy. "Critique is a Philosophy of the Spirit ", Anthropology \& Materialism [Online], Special Issue | I | 2017, Online since 02 March 2017, connection on 04 December 2018. URL : http:// journals.openedition.org/am/731; DOI : 10.4000/am.731.

4. SCHOLEM, Gershom. 1989. Walter Benjamin: a história de uma amizade. p. 73.

5. Benjamin, só publicou em vida dois livros. Todas as outras das suas publicações, mesmo as mais importantes, tiveram que ser publicadas separadamente em pequenas partes e em diversas revistas. Como não conseguiu a sua cátedra de livre docente pela Universidade de Frankfurt, da mesma forma como não migrou para a Universidade Jerusalém com seu amigo Scholem, sua potencialidade filosófica e crítica não teve acesso a Academia. Desta forma, literalmente como um outsider ele seguiu, pelos tortuosos caminhos da produtividade reflexiva autônoma. Enquanto vida prática, houve muita dificuldade e fracasso. Enquanto vida reflexiva, ele foi livre. Scholem o define também como um outsider, primeiro como um erudito e segundo quanto ao seu conhecimento literário. SCHOLEM, Gershom. 1989. Walter Benjamin: a história de uma amizade, p. 148.

6. ROCHLITZ, Rainer. 2003. O desencantamento da arte, p. 08.

7. ROCHLITZ, Rainer. 2003. O desencantamento da arte, p.07, 08 e 10.

8. BENJMAIN, Walter. Sobre o conceito de História.

9. SCHOLEM, Gershom. 1989. Walter Benjamin: a história de uma amizade, p. 190.

10. SCHOLEM, Gershom. 1989. Walter Benjamin: a história de uma amizade, p. 56, 65, 96, 99, 111, 124, 128, 140, 142, 196 197, 204, 207, 208.

11. BENJAMIN, W. 2011. Curriculum Vitae Dr. Walter Benjamin. p. 7-8.

12. Apesar de comprovarmos através de sua carta a Kitty Marx Steinschneider de 04.01.1936, que ele havia se afastado de sua herança fichteana, suspeitamos que os motivos pelos quais ele encobriu este rastro se deu primeiramente pelo posicionamento político da época na Alemanha em plena ascensão do nazismo. Outro motivo importante se deu também por causa do posicionamento filosófico e político que Heidegger teve nesta época, pois de acordo com Richard Findler, em seu trabalho Was Fichte Heidegger's political Fürsprecher? Fichte and Heidegger on

language, Heidegger se utilizou da filosofia de Fichte para expor determinados posicionamentos que impulsionariam o discurso nazista na constituição de sua ideologia. Sem falar também que, como constata Howard Caygill, em Walter Benjamin a Graphic Guide, Benjamin fez o mesmo curso do neo-kantiano Heinrich Rickert com Heidegger em Freiburg em Bresgau no ano de 1912. Por fim, é importante mencionar que de certa forma, Benjamin acompanhava a distância os passos de Heidegger, afinal, de forma estranha, mas não tão coincidente estes dois pensadores estavam ligados pelo mesmo questionamento filosófico, a questão do ser através da linguagem, como expõe Wolfram Eilenberger em seu livro Tiempo de Magos. Ver: CAYGILL, H.; COLES, A.; KLIMOWSKI, A. 2014. Walter Benjamin a graphic guide. Icon Books Ltd, p. 14 - 15.; EILENBERGER, W. 2019. Tiempo de Magos. Taurus.; FINDLER, Richard. 1999. Was Fichte Heidegger's political Fürsprecher? Fichte and Heidegger on language. 1999. Symposium, Volume 3, Issue 2, Fall 1999. URL: 
https://www.pdcnet.org/symposium/content/symposium_1999_0003_0002_0169_0183 ; DOI: 10.5840/symposium19993218.

13. O termo negligenciado pode parecer forte no momento em que ele está sendo empregado aqui, contudo infelizmente é necessário usá-lo. Isso, se dá, justamente, por um pensamento engessado que algumas universidades do Brasil, alguns professores e alguns pesquisadores, vem adotando, sem nenhuma explicação coerente, na minha própria opinião, em não propor novos dimensionamentos a pesquisa em filosofia. Um exemplo disso, é, que a maioria das pesquisas acabam sendo conduzidas de forma restrita, e da forma com os interesses pessoais do orientador pesquisa. Ou seja, se pesquisa o que ele deseja pesquisar e não as propostas que são avaliadas. Sem falar que, numa característica estrutural de investigação científica, os principais órgãos de fomento do governo brasileiro, recusaram esta presente proposta de investigação, com pareceres completamente esdrúxulos, e ainda informando que a proposta não tinha nenhum respaldo teórico. Ou seja, é simplesmente negar trabalhos como o de Élise Derroitte ou de Wolfram Eilenberger que foram recentemente publicados, o primeiro em revista especializada de pesquisa em dezembro de 2018 e o segundo em formato de livro em março de 2018, em três línguas estrangeiras desde o seu lançamento. Por isso, afirmamos que sim, este posicionamento a respeito das influências de Fichte na filosofia de Benjamin, vieram sendo negligenciados ao longo de todos estes anos.

14. SCHOLEM, Gershom. 1989. Walter Benjamin: a história de uma amizade, p. 19.

15. Scholem nos apresenta o seguinte relato: "A lista bastante grande e esmerada dos livros que Benjamin lera, que ele me passou nessa época e consta do seu espólio (de 1915 em diante), está repleta de romances policiais". SCHOLEM, Gershom. 1989. Walter Benjamin: a história de uma amizade, p. 42.

16. Benjamin tinha como um troféu em sua sala, um pôster de um tatuador que adquirira em Copenhague e exibia com muito orgulho. Ou seja, tudo o fascinava. Coisas que aparentemente seriam consideradas lixo para a academia em geral, para ele eram obras da mais minuciosa preciosidade. SCHOLEM, Gershom. 1989. Walter Benjamin: a história de uma amizade, p. 46.

17. 0 termo dispositivo do qual nos referimos aqui tem o mesmo significado do qual Giorgio Agamben apresenta em seu trabalho O que é um dispositivo?. AGAMBEN, Giorgio. 2009. O que é um dispositivo, in $\mathrm{O}$ que é contemporâneo? e outros ensaios.

18. WITTE, Bernd. 2017. Walter Benjamin uma biografia.

19. SONTAG, Susan. 1986. Sob o signo de Saturno, p. 101.

20. É importante frisar que atualmente na Alemanha estão saindo um novo conjunto das obras de Benjamin, desta vez uma versão crítica pela editora Suhrkamp sendo disponibilizados 09 exemplares de uma coleção total com 21 títulos. As edições que realizamos a contagem da tabela abaixo provem das obras disponíveis on-line. Ver: «<https://www.suhrkamp.de/werkausgabe/ werke_und_nachlass_kritische_gesamtausgabe_gebunden_16.html $>>$ e $<<$ https://archive.org/ >>. 21. O termo maneirismo atribuído a Benjamin é uma forma bastante peculiar de Scholem descrevê-lo. Scholem emprega este termo algumas vezes para constatar um certo traquejo, peripécias, melindre ou trapaça que Benjamin utilizava em suas questões pessoais e as vezes intelectivas que, de certa forma, encobria o verdadeiro sentido das coisas dando assim uma aparência figurada ou ainda mascarada. SCHOLEM, Gershom. 1989. Walter Benjamin: a história de uma amizade, p. 18; p. 123; p. 200.

22. Distração aqui terá também a conotação do que Benjamin irá desenvolver, através de suas influências da filosofia fichteana e que chamaremos aqui de dialética da distração. Todo o proceder desta dialética se baseia na estruturação do axioma fichteano no desenvolvimento da consciência reflexiva do EU. Com o objetivo de provar não só esta influência, mas implicar logicamente estas influências em uma demonstração formalizada como base do seus sistema espectral em um dos seus mais famosos, A obra de arte na era da sua reprodutibilidade técnica.

23. Grifo nosso. BENJAMIN, Walter. 2011. Origem do Drama Trágico Alemão, p. 113. 
24. BENJAMIN, Walter. 2009. As passagens. p. 510

25. BENJAMIN, Walter. 2009. As Passagens. p. 766

26. BENJAMIN, Walter. 2009. As passagens. p. 818.

27. PRESSLER, Gunter K. 2006. Benjamin Brasil. Segundo Pressler, o primeito texto de Walter Benjamin publicado no Brasil foi no ano de 1959, cuja tradução foi feita por Dora Rocha, uma tradução dos seus textos publicados em língua francesa.

28. A necessidade desta afirmação se baseia especificamente na escassez de trabalhos que envolvem uma análise pormenorizada da Filosofia da Linguagem de Walter Benjamin. Desde sua chegada ao Brasil o foco sempre foi especificamente a perspectiva estética. Contudo, atualmente, este quadro, talvez possa mudar, com a mudança de paradigma sobre a leitura dos seus trabalhos. Como mais um fato deste tipo de leitura, sugerimos também a leitura da publicação dos artigos na Revista USP № 15 Dossiê Walter Benjamin de 1992.

29. A respeito das traduções feitas para o Brasil do texto da A obra de arte na era da sua reprodutibilidade técnica, existe um trabalho de conclusão de curso da Universidade Federal da Paraíba - Campus IV - UFPB, intitulado Processos, tradução e edição: porque discutir a estrutura do texto A obra de arte na era da sua reprodutibilidade técnica de Walter Benjamin no Século XXI? de Eliana Vasconcelos Medeiros Nascimento, em que a autora apresenta todos os problemas relacionados as diferentes versões do texto A Obra de Arte, que chegaram ao Brasil desde sua primeira publicação até os dias de hoje, com sua última edição publicada em 2017. A autora concluí o trabalho sugerindo uma nova versão da tradução do texto, expondo em sua íntegra o que deveria vir no corpo do texto, para que sua análise e compreensão sejam ampliados para o público brasileiro. Esta conclusão já é realidade na Alemanha, com o lançamento em da edição crítica deste mesmo texto, editados pela Suhrkamp, desde 2012. Infelizmente, a publicação feita em 2017 no Brasil, sendo esta última a "mais atual", não expõe na sua completude todo o processo de composição deste texto de Benjamin, deixando ainda a lacuna sobre uma melhor versão do texto para o português, já que é apenas uma parte da versão alemã. Ver: NASCIMENTO, E. V. M. 2017. Processos, tradução e edição: porque discutir a estrutura do texto A obra de arte na era da sua reprodutibilidade técnica de Walter Benjamin no Século XXI?. Monografia de Graduação, UFPB Campus IV..; BENJAMIN, Walter. 2012. Das Kunstwerk im Zeitalter seiner technischen Reproduziertbarkeit. Suhrkamp Verlag.

30. Os cinco volumes sobre a ditadura militar de Elio Gaspari apresentam todo o panorama deste momento histórico vivido no Brasil. Os títulos são: A Ditadura Envergonhada, A Ditadura Escancarada, A Ditadura Derrotada, A ditadura Encurralada e A Ditadura Acabada.

31. GRUNNEWALD, José Lino. 1969. A idéia do cinema. Rio de Janeiro: Editora Civilização Brasileira S. A.

32. O termo escolhia vem entre aspas, pois durante o ano de 1964, se instaurava no Brasil, um Golpe Militar, que decretou o regime de ditadura no país cuja censura era uma das práticas comuns dos materiais que poderiam circular no país e que teve o seu fim, somente no ano de 1985.

33. Um exemplo disso é a reviste eletrônica GEWEBE especializada em estudos sobre o pensamento benjaminiano organizadas por um comitê científico na Universidade Estadual do Ceará - UECE. Ver: <<www.gewebe.com.br>>.

34. Scholem nos apresenta a definição de Golem em duas distintas formas. A primeira, relacionada ao rabi de Praga, que se chamava Rabi Judá Loew Bezalel e a segunda a uma atualização deste conceito, o que Scholem irá definir como o Golem de Rehovot. Nosso conceito de Golem Benjaminiano está mais para uma junção destes dois conceitos e na qual o definiremos e o apresentaremos posteriormente como o Golem de Saturno. Ver, SCHOLEM, Gershom. 1994. O Golem, Benjamin, Buber e outros justos: judaica I, p. 89 - 96.

35. SCHOLEM, Gershom. 1989. Walter Benjamin: a história de uma amizade. p. 107.

36. SCHOLEM, Gershom. 1994. O Golem, Benjamin, Buber e outros justos: judaica I, p. 204. 
37. Idem, p. 204.

38. João Barrento em sua obra Limiares sobre Walter Benjamin, oscila em confirmar contundentemente que existe um sistema filosófico em Walter Benjamin. O autor, tradutor e crítico da filosofia benjaminiana afirma que há pequenos sistemas, ou formas sistemáticas através de imagens, do qual Benjamin teria seguido, para não cair em sistemas filosóficos abstratos. "Não sendo um pensamento sistemático, existem núcleos de sistematicidade dentro dele. É possível, ao logo de toda obra, muito dispersa e fragmentária, reconstruir determinados núcleos de significação, que aparecerem e reaparecem, construindo o "sistema" de Walter Benjamin. Contudo, o que o crítico João Barrento não descarta é a possibilidade de reconstrução destes micro sistemas. Ou seja, a possibilidade de um sistema fechado nunca foi o objetivo de Benjamin, mas sim de uma forma sistemática aberta que estruturasse sua filosofia. Por isso, pensar que seu sistema é um sistema com base na linguagem, possibilita estes aparecimentos e reaparecimentos colocados por João Barrento. Esta características provém das influências de suas leituras da filosofia de Fichte. BARRENTO, João. 2013. Limiares sobre Walter Benjamin, p. 51.

39. EILENBERGER, Wolfram. 2019. Tiempo de Magos.

40. CHALMERS, Alan F. 1993. O que é ciência afinal?

41. OLIVEIRA, Manfredo Araújo. 2015. Reviravolta linguístico-pragmática na filosofia contemporânea.

42. Nossa discussão a respeito da técnica sob a perspectiva da filosofia espectral da linguagem e provenientes das influências de Fichte, serão apresentadas a parte em um outro capítulo, expondo uma releitura do texto A obra de arte na era da sua reprodutibilidade técnica.

43. WITTGESNTEIN, Ludwig. 2008. Tractatus Logicus-Philosophicus. p. 55

44. BENJAMIN, Walter. 2011. Origem do Drama Trágico Alemão, p. 26.

45. PLATÃO. 2001. Crátilo.

46. A divisão conceitual a respeito da existência de dois Wittgenstein demarca a superada que o próprio filósofo inglês fez em relação a sua filosofia. O primeiro Wittgenstein é encabeçado pelo seu Tractatus Lógico-Philosophicus, enquanto o segundo Wittgenstein tem por base seu trabalho decorrente das Investigações Filosóficas.

47. A problemática da técnica demarca historicamente e socialmente como o sujeito contemporâneo se configura. Benjamin, que traz sua perspectiva com o seu trabalho A obra de arte na era da reprodutibilidade técnica. Mas é em seu texto Experiência e Pobreza que o autor irá apresentar o enfraquecimento da transmissão do conhecimento na/pela linguagem oriundos também de um avanço da técnica. BENJAMIN, Walter. 2010. Experiência e Pobreza, in O Anjo da História.

48. É importante deixar claro que não estamos negando as propostas idealistas, pois elas servem de suporte. Contudo é importante demarcar que a maioria dos grandes sistemas filosóficos apresentam propostas boas e importantes ao mesmo tempo que entraves que as restringem. Fichte neste ponto, além de propor uma forma sistemática evolutiva e adaptativa tem em sua engenharia um mecanismo de autocorreção que é sempre a sua possibilidade de revisão normativa enquanto ação, ou seja, sua Tathandlung. Este mecanismo é o que Benjamin enaltece diversas vezes em sua tese de doutoramento na sentença "o seu pensar, do pensar do pensar" que se desdobrará em sua filosofia como o trabalho da crítica. BENJAMIN, Walter. 2002. O conceito de crítica de arte no romantismo alemão, p. 34.

49. Benjamin decompõe da definição fichteana de Tathandlung e a expõe de maneira mais pormenorizada, justificando assim o seu objetivo futuro em relação a ação da crítica. BENJAMIN, Walter. 2002. O conceito de crítica de arte no romantismo alemão, p. 37.

50. O termo mundo aqui se refere diretamente ao termo realidade. Tal qual Wittgenstein emprega o termo mundo em sua sentença 1.1 do Tractatus.

51. O conceitos acima citados, necessariamente provém das definições apresentadas pela Computação. Nosso entendimento é que Benjamin pensa a linguagem como um jogo. Recorremos 
aos termos da área da computação, por um interesse estético contemporâneo de "brincar"com esta terminologia técnica, já que, o Século XXI, se iniciou com o famoso Bug do Milênio ou Bug Y2K.

52. Grifo nosso. BENJAMIN, Walter. Sobre o conceito de História.

53. Grifo nosso. FRANK, Manfred. 2015. Filosofia como <<aproximación infinita >> Consideración a partir de la $<$ constelación $>>$ del primer romantismo alemán, in Auswege aus dem Deutschen Idealismus, p. 312 - 313.

54. Grifo nosso. FRANK, Manfred. 2015. Filosofia como <<aproximación infinita >> Consideración a partir de la «constelación >> del primer romantismo alemán, in Auswege aus dem Deutschen Idealismus, p. 312.

55. VIVEIROS DE CASTRO, Eduardo. 2015. Metafísicas canibais.

56. (...) subsiste entre nós uma forma de atividade que, no plano técnico, permite perceber perfeitamente aquilo que, no plano da especulação, pôde ser uma ciência que preferimos antes chamar, "primeira" que de primitiva: é aquela comumente designada pelo termo, bricolage. Em sua acepção antiga, o verbo bricoler aplica-se ao jogo de péla e de bilhar, à caça e à equitação, mas sempre para evocar um movimente incidental: o da péla que salta muitas vezes, do cão que corre ao acaso, do cavalo que se desvia da linha reta para evitar um obstáculo. E, em nossos dias, o bricoleur é aquele que trabalha com as suas mãos, utilizando meios indiretos se comparados com os do artista. Ora, a característica do pensamento mítico é a expressão auxiliada por um repertório cuja composição é heteróclita e que, mesmo sendo extenso, permanece limitado: entretanto, é necessário que o utilize qualquer que seja a tarefa proposta, pois nada mais tem à mão. Ele se apresenta, assim, como uma espécie de bricolage intelectual, o que explica as relações, que se observam entre ambos. Assim, como o bricolage, no plano técnico, a reflexão mítica pode alcançar, no plano intelectual, resultados brilhantes e imprevistos (...) o bricoleur está apto a executar um grande número de tarefas diversificadas, porém ao contrário do engenheiro, não subordina nenhuma delas a obtenção de matérias-primas e de utensílios concebidos concebidos e procurados na medida do seu projeto: seu universo instrumental é fechado, e a regra do seu jogo é sempre arranjar-se com os "meios-limites", isto é, um conjunto sempre finito de utensílios e materiais bastante heteróclitos, porque a composição do conjunto não está em relação com o projeto do momento nem com nenhum projeto em particular mas é o resultado contingente de todas as oportunidades que se apresentaram para renovar e enriquecer o estoque ou para mantêlo com os resíduos de construções e destruições anteriores. LÉVI_STRAUSS, Claude. 2008. O pensamento selvagem, p. $32-33$.

57. No seu estudo sobre as Afinidades Eletivas de Goethe, Benjamin apresenta uma longa exposição a respeito do conceito de Teor de Verdade que supera a mera aparência. O termo é Bloß Schein. Termo que provém da filosofia hegeliana, no momento quando Hegel discute sobre Forma e Conteúdo. O que ele faz, de acordo com um maneirismo é encobrir com a mera aparência de fragmentário, sua estrutura sistemática. Sua estratégia é genial. Sobre as Afinidades Eletivas, ver: BENJAMIN, Walter. 2011. As afinidades eletivas de Goethe.

58. Carta de Kant rechaçando a proposta de Fichte 10 anos após o lançamento da sua Doutrina da Ciência. Ver: KANT, I. 2007. La declaración pública de Kant contra Fichte. Trad. F. Moledo, IDEAS Y VALORES, 56/133. Disponível em: $\ll$ http://www.scielo.org.co/scielo.php? pid=S0120-00622007000100008\&script=sci_arttext >>

59. 0 termo está entre aspas, porque Benjamin não faz isso de fato. Ele utiliza de seu maneirismo e esconde estas influências. Razão da qual, fortalece mais ainda nossa proposta, pois quando se cruza seus textos com os de Fichte, é revelado a matéria bruta do seu sistema.

60. Scholem chamará a atenção para o olhar de Benjamin em dois momentos. Em um primeiro momento, ele define o olhar míope de Benjamin, pela postura que adotava para apresentar-se em público. "Esta postura característica prendia-se provavelmente à sua acentuada miopia, que lhe tornava difícil focalizar grupos em movimento". Mas também, há uma dupla faceta desta miopia. 
E é esta que deveremos seguir, pois, quando estava só com Scholem, Benjamin gostava de olhá-lo com os olhos bem abertos. Isso mostra não só uma atenção maior que Benjamin tinha em suas conversas privadas com Scholem, mas também denota uma outra forma de olhar, um olhar atento, que cega a visão, mas aguça a audição. Benjamin escreve sobre seu ensaio de Kafka, "Aquele que ouve atentamente, não vê". Ou seja, enquanto que por todos estes anos os direcionamentos, as análises e as discussões sobre a filosofia de Benjamin, que produziram coisas importantíssimas, se fixaram mais na imagem do que sua filosofia passava, esqueceram de ouvir o que ela dizia. Ver SCHOLEM, Gershom. 1989. Walter Benjamin: a história de uma amizade, p. 14 e p. 16. BENJAMIN, Walter. Franz Kafka. 1987. A propósito do décimo aniversário de sua morte, in Magia e técnica, arte e política.

61. A composição da malha estrutural do sistema espectral da linguagem de Walter Benjamin é composta pelos textos de juventude entre 1906 e 1919, em um primeiro momento, e sua expansão até 1925, ano do qual ele escreve Origem do Drama Trágico Alemão.

62. Especificamente estas duas obras, pelo que conseguimos até agora consultar nas publicações de Benjamin, não aparecem em nenhuma referência. Ou seja, aparentemente ele não as leu, ou não deu muita importância, como a Doutrina da Ciência e Deduzierter Plan einer zu Berlin zu errichtenden höheren Lehranstalt, die in gehöriger Verbindung mit einer Akademie der Wissenschaften stehe. Este último segue ainda sem tradução para o português, o espanhol e o inglês.

63. BENJAMIN, Walter. 2018. Sobre a linguagem em geral e sobre a linguagem do homem.

64. BENJAMIN, W. 2017. A obra de arte na era da reprodutibilidade técnica.

\section{RESUMOS}

O presente trabalho tem como objetivo inicial apresentar as heranças constituintes da filosofia fichteana como estrutura do sistema espectral da linguagem da filosofia de Walter Benjamin. De acordo com os dados analisados de alguns textos importantes de juventude, cartas, artigos publicados, sua tese de doutoramento bem como o trabalhos desenvolvidos ao longo de sua errante carreira acadêmica, pudemos constatar como Benjamin encobriu de forma astuta, provenientes do seu maneirismo, as influências do pensamento de Fichte. Os motivos desta decisão podem ser determinados pelos posicionamentos políticos da época em que viveu, as dificuldades acadêmicas pelas quais passou em vida, mas ao mesmo tempo, pela consolidação de uma metodologia inovadora advinda dos conhecimentos expostos por Dieter Heinrich, durante o firmamento do Primeiro Romantismo Alemão, cuja fundamentação teórica se utilizava na complementação de puzzles oriundos de variados posicionamentos teóricos a fim de constituir uma malha tão fina quanto a teia da aranha. Como resultado deste procedimento, Benjamin conseguiu codificar suas teorias numa nova perspectiva sistemática de compreensão da realidade que moldariam as formas e os sentidos do dizer do ser. Como proceder por este posicionamento se pôs como um desafio de se seguir a contrafluxo do que se é exposto a respeito da filosofia benjaminiana, delimitamos como meta, montar num tigre e dar um salto em direção ao passado, com a finalidade de repararmos a dívida histórica que as pesquisas sobre a filosofia de Benjamin tem em relação com as influências do pensamento de Fichte. Assim, com o intuito de interconectar os múltiplos saberes e seus desdobramentos não seguiremos os rastros deixados por Benjamin, mas sim, decodificaremos sua metodologia para honrarmos as influências presentes que a filosofia de Fichte tem em seu sistema. 
ÍNDICE

Keywords: sistema espectral da linguagem, Fichte, codificação, decodificação, crítica

\section{AUTOR}

\section{THEOFILO MOREIRA BARRETO DE OLIVEIRA}

Vrije Universiteit Brussel 